\title{
An Assessment of Social and Economic Indicators in Pilot REDD+ Communities of Afi/Mbe in Cross River State, Nigeria
}

\author{
Adeniran Akanni \\ Department of Environmental Planning, Climate Change, Lagos State Ministry of Environment, Lagos, Nigeria \\ Email address: \\ adeniranakanni@yahoo.com

\section{To cite this article:} \\ Adeniran Akanni. An Assessment of Social and Economic Indicators in Pilot REDD+ Communities of Afi/Mbe in Cross River State, Nigeria. \\ International Journal of Environmental Protection and Policy. Vol. 6, No. 3, 2018, pp. 63-70. doi: 10.11648/j.ijepp.20180603.11
}

Received: August 29, 2018; Accepted: September 12, 2018; Published: September 29, 2018

\begin{abstract}
Poverty alleviation for forest dependent communities is one of the key objectives of Reducing Emission from Deforestation and Forest Degradation-plus (REDD+), apart from climate change mitigation and biodiversity conservation. There is need to avoid adverse social and economic consequences by adopting strong safeguard and measures if REDD+ is to have positive impacts for climate mitigation and biodiversity conservation. A Participatory Community Wellbeing Assessment (CWA) tool was used to measure some socio-economic indicators as it relates particularly with regard to basic needs, safety needs, belonging needs, self-esteem as well as spiritual needs in eight selected communities in Afi/Mbe, one of the pilot REDD+ project sites in Cross-River State, Nigeria. The findings reveal that $62.5 \%$ of the communities sampled had much decline in their food security from pre-REDD+ period while $37.5 \%$ of the communities had slight decline on the same indicator. The trend in reduction in food security in the communities particularly with reference to pre-REDD + era is also reflected in trends in savings. $62.5 \%$ of the communities' sampled had decline in savings indicator. This has some implication on the security need due to inability to buffer for the future. The alternative livelihood indicator showed that only $25 \%$ of communities sampled has one form of alternative livelihood or the other. The effect of REDD+ on the basic need indicator is also reflected in the inability of resident farmers to build new houses of their own. Outsiders like Civil servants now come into the communities to erect houses. This poses a serious equity issue for local residents. A set of recommendations for improving alternative livelihoods, health and education in the communities are proffered in addition to means of leveraging REDD+ to achieve sustainable development objectives in Nigeria. The study can form a basis for formulation of policies and measures with regards to REDD+ social safeguards and equity in REDD+ process in line with UN-REDD proposed social and environmental safeguards criteria.
\end{abstract}

Keywords: REDD+, Safeguards, Community Well-Being Assessment

\section{Introduction}

Reducing Emissions from Deforestation and Forest Degradation (REDD+) is a program through which people who conserve tropical forests in developing countries are monetarily compensated for avoided deforestation and forest degradation activities as part of climate change mitigation strategy. The plus (+) in REDD implies some additions that will conserve, enhance carbon stock and contribute to sustainable forest management. Therefore REDD + has emerged as a suite of policies, institutional reforms and programs which will provide developing countries monetary incentives to reduce greenhouse gas emissions and enhance economic development by preventing the destruction of their forests [1]. REDD + has further been designed to offer opportunities for reducing carbon emissions through avoided deforestation and degradation of the forest through transfer of resources between social actors, which aim to create incentives based on interest of individual and collective land use decisions with a social interest in natural resources management [2]. REDD+, therefore, has as one its objectives to contribute to poverty alleviation and improved rural livelihood through the mechanism of Payments for Ecosystem Services (PES) [3, 4]. 
Nigeria as a country is now implementing REDD+. The Nigeria REDD+ program was designed with objectives to contribute to climate change mitigation through improved forest conservation while enhancing sustainable community livelihoods [5].

According to a statement by the UN-Resident Representative to Nigeria on the Country's REDD+ initiative, "The REDD+ mechanism represents an example of climate finance through which a range of other development objectives can be achieved simultaneously, as it not only results in the reduction of GHG emission but could also ensure better governance, protection of biodiversity while generating social benefits and poverty reduction"1.

The United Nations Framework Convention on Climate Change (UNFCCC) through Decision 1/CP.16 has set a mechanism for developing countries to contribute to climate change mitigation actions in the forestry sector by undertaking, according to national capabilities and circumstances, activities that will reduce emissions from deforestation, forest degradation, conservation of forest carbon stock, sustainable management of forest and enhancement of forest carbon stock [1]. This is a demonstration of principle of common but differentiated responsibility with regards to climate change mitigation actions as, developing countries, who contribute little to global Green House Gas (GHG) level are now required to play a role in its mitigation [6]. Nonetheless, this action also falls under Nationally Appropriate Mitigation Actions (NAMAs) in the context of sustainable development by developing country parties under the UNFCCC [7].

The recent 2015 Paris Climate change agreement has set a global scheme for Reducing Emission from Deforestation and forest Degradation (REDD)-plus, there has been some progress on moving forward with REDD+ agenda at domestic and bilateral levels due to support offered by international agencies like the World Bank, United Nations collaborative partnership in REDD, UN-RED among others. Also, partnerships forged between countries like Indonesia, Brazil and Congo on one hand and Norway on the other hand has helped in no small measure in moving forward the REDD+ agenda [8].

While the modalities of REDD+, a new global initiative, aimed at conserving tropical forest in developing countries as a climate change mitigation measure is now taking shape , research has not yet been conducted to know the immediate impact of the REDD+ readiness activities albeit, the moratorium or outright ban on forest extraction activities during the REDD+ readiness phase on the livelihood of vulnerable forest dependent communities who depend on income from forest extraction activities as well as forest acting as indigenous landscape which enhances their cultural integrity. Hence, we need to know how REDD+ can contribute to the socio-economic development of forest dependent communities as well as develop safeguard Policies

\footnotetext{
1 Daily Independent Newspaper, 12, June, (2011): http://allafrica.com/stories/201106130690.htm
}

and Measures (P \& M) based on the peculiarity or context of the communities to "safeguard" their interest so that REDD+ delivers multiple benefit.

Some specific risks of REDD+ for local communities include loss of traditional territories and restriction of land and natural resource rights, lack of equitable benefit sharing to the communities, exclusion from designing of policies and loss of traditional ecological knowledge [9]. REDD + also poses significant risk for indigenous people especially with regards to their livelihoods and culture [10]. The Nigeria REDD+ project document identified some risks which include loss of revenue or employment for forest communities', disruptions of traditional customs and conflict over ownership rights for land and carbon [5] This is particularly important since most countries tie the right to benefit from carbon sequestration and storage to land rights [11]. Therefore, the interest and concerns of indigenous communities in REDD+ implementation should be given prime consideration in program design $[12,1]$. This, apart, from helping in achieving poverty alleviation in forest communities as one of the objectives of REDD+, is also important in achieving the other twin objectives of REDD+: climate change mitigation and biodiversity conservation.

Using a Participatory Community Wellbeing Assessment (CWA) tool, this study aims to measure some socioeconomic parameters as it relates to basic needs(food, health, shelter), safety needs (settled tenure, savings, alternative source of income, Insurance, community fund, conservation activities), belonging needs (social groups, women in economic activities, women in leadership positions, equity in access resources, equity in access to leadership, equity in benefit sharing and traditional institution), self-esteem (autonomy to regulate resources, autonomy in economic choices, autonomy over local governance, education, confidence in negotiation with external partners) and spiritual need (sacred places, spiritual leadership, traditional festivals and practice of spiritual beliefs [13] in eight selected pilot REDD+ communities in Afi/Mbe , Cross River State, Nigeria.This is to identify risks associated with REDD+ implementation that could lead to evidence-based recommendations to help formulate social safeguards policies within REDD + context and in line with Cancun declaration [1] and the proposed UN-REDD social and environmental principles and criteria [14].

\section{Study Site}

The Afi/Mbe consists of contiguous communities around the Afi/Mbe Mountains in Boki LGA.

According to 1991 Population census figures, Boki LGA has a population of 156,617 .This has grown to 210,843 based on 2006 population census figures [16].

Apart from Okwango Division of Cross River National Park, most of the endangered Cross River Gorilla, Gorilla gorilla diehli is housed in Afi/Mbe Mountains making this area a biodiversity hotspot which should be given prime conservation priority. The importance of conserving this area is further 
reinforced by the listing of Afi Mountains as an Important Bird Area (IBA) for hosting one of the largest migratory swallow, Hirundo rustica in Africa ${ }^{2}$.The Afi complex remains the largest forest block apart from Cross River National Park in the State. It includes Afi River forest reserve and Afi Mountain Wildlife Sanctuary (AMWS).The Afi Mountain Wildlife Sanctuary was established in 2000 covering an area of $100 \mathrm{Km} 2$ and this divides the Afi forest reserve from Mbe Mountains. The Afi complex has sixteen villages and farms. The Mbe complex on the other hand has Mbe forests which covers $100 \mathrm{Km} 2$ and it is comprises of nine surrounding Communities [17].

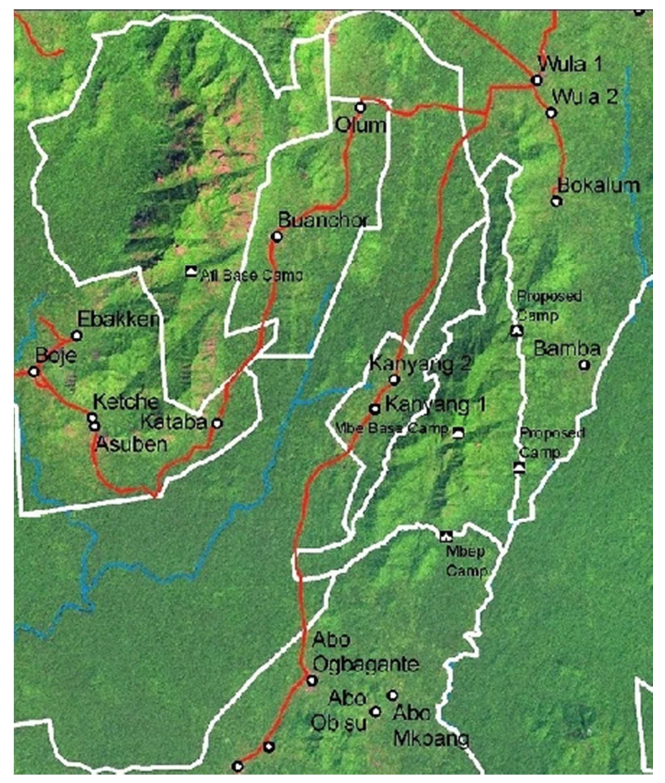

Figure.1. Showing Afi/Mbe map and the communities [15].

According to Governor's Climate Forum [18], deforestation rate between 1991-2001 for Afi forest reserve is 25.1\%.The forested area declined from $402.87 \mathrm{Km} 2$ in 1991 to $301.51 \mathrm{Km} 2$ in 2001 losing an area of $101.36 \mathrm{Km} 2$ to deforestation. The need to clear forest for agricultural land expansion is the chief reason for forest degradation as other factors according to GCF include unsustainable agricultural practices, commercial logging, cattle grazing and poor enforcement of forest policies [18].

\section{Methodology}

A Community Wellbeing Assessment (CWA) uses multiple indicators to map socio-economic indices and the preference ranking approach advocates local participation and interactive knowledge sharing among participants [19]. Many CWA frameworks exist such as based on Maslow's framework [20] and Clarke's model of well-being [21].

A community well-being assessment questionnaire developed by UNU-IAS researcher was used [13]. It consists of quantitative approach with a set of defined criteria for scoring each indicator of community well-being. The scoring of the indicators in the

\footnotetext{
2 Afi Mountain Wildlife sanctuary blog. http://www.cometonigeria.com/whattodo/adventure/afi-mountain-wildlifesanctuary-cross-river-state.
}

questionnaire generally range from -2 (much decline) to 2 (much increase). Each community has to debate the indicator that affects them since the commencement of REDD+ activities and hence initiates a discussion on the prospects and consequences of the project within the community. An agreement is thus reached by members of the communities on the score for such indicator. The scores are indicators of trends based on perspectives of a group of quantifiable parameters where perceptions of respondents are evaluated. In scoring, all parameters are given equal weightage, and the scores are used to look at trends.

Apart from scoring each indicator in the questionnaire, additional comments which help explain further the score for the indicators were also obtained.This helped in explaining what could not be captured with the assessment tool and are taken into consideration in discussing the results.

A field visit was conducted where the questionnaires were administered to the cluster of communities in Afi and Mbe Mountains, Boki LGA in Cross River state of Nigeria. Interviews were conducted with representatives of 8 communities with four communities each sampled from Afi (Buanchor, Enyi, Kayang1, and Wula1) and Mbe (AboOgbagante, Bamba, Kayang1, Wula1) respectively. The purpose of the interview was explained to the respondents and interview was based on pre-designed questionnaire with information collected in a small group of community representatives.

The representatives of each community provided answers to the questions regarding changes in their livelihood activities, local governance issues, benefit distribution using the pre REDD + as reference point.The information obtained also concern benefit sharing mechanisms and cultural practices in the communities.

Radar (Spider) diagram from Excel Statistical Packages was used to analyze the trends of each indicator of well-being in the community studied.

\section{Result and Discussion}

The framework of community well-being measures components comprising an element of basic, safety, belonging and self-esteem needs which has social, material and spiritual dimensions. The scoring result (quantitative) for all the indicators in the questionnaire is detailed in the Annex 1.

\subsection{Basic Needs}

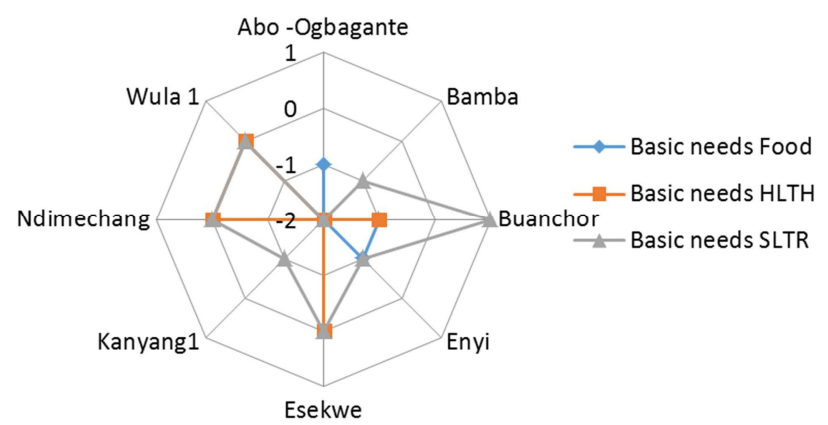

Figure 2. Radar (Spider) diagram showing trends of Basic needs in the Communities. 
The indicators of the basic need according to the framework consist of food, health and shelter. The Radar diagram in Figure. 2 above shows the trend of each of the basic need indicator in the eight communities sampled with most of the indicator showing score of 0 to -2 .

Analysis showed that $62.5 \%$ of the communities sampled had much decline $(-2)$ with regards to food indicator while $37.5 \%$ of communities sampled had slight decline $(-1)$ to the food indicator.

$50 \%$ of communities sampled had much decline in health indicator (-2) while $12.5 \%$ of the communities sampled recorded slight decline (-1) in the health indicator. $37.5 \%$ of communities sampled recorded no change $(0)$ in the health indicator.

Furthermore, $12.5 \%$ of the communities sampled had much decline $(-2)$ in shelter need while $37.5 \%$ of the communities sampled had slight decline (-1) for this indicator. Another $37.5 \%$ of communities sampled recorded no change (0) in shelter indicator. However, Buanchor, representing $12.5 \%$ of communities sampled had slight increase (1) for the shelter indicator.

\subsection{Safety Needs}

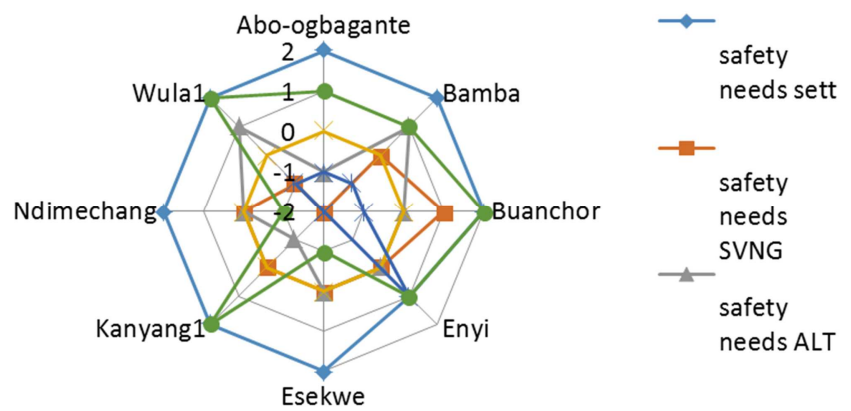

Figure 3. Spider diagram showing trends of safety needs of communities.

Safety needs according to the framework adopted in this study include land tenure (sett.), savings, and alternative source of livelihood and community funds. Figure. 3 above shows different components of the safety needs in the communities sampled. Generally, there seems to be an increase in trend for land tenure as perceived by the communities. However, in terms of savings and alternative livelihood, there appears to be some decline as show by the trends in fig 3 above.

Further analysis showed $87.5 \%$ of the communities sampled claimed they had much improvement (score 2) in land tenure indicator $12.5 \%$ of communities sampled had slight improvement (score 1) for this indicator. $62.5 \%$ of communities sampled witnessed no appreciable change (score 0) in the level of their savings since REDD+ began. $12.5 \%$ of communities sampled witnessed much decline (score -2), while $12.5 \%$ of communities sampled witnessed slight decline (score -1).

$50 \%$ of communities sampled had no measurable change (score 0 ) in their level of alternative livelihood since REDD+ activities started while $25 \%$ of communities sampled had slight decline (score -1) in livelihood activities and another
$25 \%$ of communities sampled had slight increase(score 1) in their livelihood activities.

$100 \%$ of the communities sampled recorded no change (score 0) in Insurance indicator (Figure 9). There was no insurance scheme prior to REDD+ program in these communities even though they recorded some natural disasters in the past like wind storm, acid rain which affected the farming activities.

\subsection{Belonging Needs}

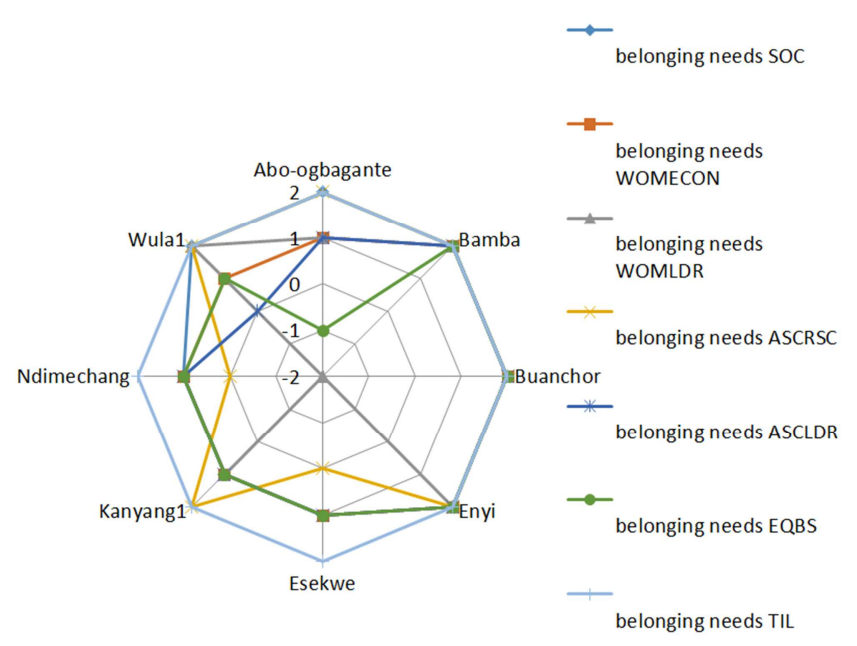

Figure 4. Showing the result of the belonging needs in the communities.

Belonging needs in the communities was assessed based of the following indicators: social groups, involvement of women in economic activities, involvement of women in leadership, equality in access to resources, equality in access to leadership, equality in benefit sharing, and traditional institution leadership. Figure. 4 above shows the trend of the belonging need indicators for different communities sampled.

$37.5 \%$ of communities sampled had much decline (score 2 ) in the community fund indicator. Half of the communities (50\%) sampled had slight decline (score -1$)$ while $12.5 \%$ of the communities sampled had slight improvement (score 1) in their community fund indicator. The importance of community funds is seen in the ability of members of the community to levy themselves in order to carry out projects in their community.

$25 \%$ of communities sampled had slight decline (score -1 ) in their ability to raise awareness for conservation activities.

$37.5 \%$ of communities sampled had slight improvement (score 1) for social group indicator while $62.5 \%$ of communities sampled had much improvement (score 2) for this indicator

$62.5 \%$ of the communities sampled had slight improvement (score 1) with the indicator for women in economic activities while $37.5 \%$ of communities sampled had much improvement (score 2) for this indicator.

$50 \%$ of the communities sampled had much improvement (score 2) in the indicator for women in leadership position while $25 \%$ of communities sampled had slight improvement for this indicator. However, two of the eight communities 
(about $25 \%$ ) of communities sampled had much decline for this indicator.

$75 \%$ of the communities sampled had much improvement (score 2) in the equity in access to resources indicator while $25 \%$ of communities sampled had no measurable change (score 0 ) for this indicator since REDD+ commenced.

$50 \%$ of the communities sampled had slight improvement (score 1) in terms of access to leadership position by every member of the community.37.5\% of communities sampled had much improvement (score 2) for this indicator. 12.5\% of communities sampled has no appreciable change $(0)$.

On equity in benefit sharing indicator, $50 \%$ of communities sampled had slight improvement (score1) while $37.5 \%$ of communities sampled had much improvement for this indicator. Only one community representing $12.5 \%$ of communities sampled had slight decline (score-1) for this indicator.

\subsection{Self-Esteem Needs}

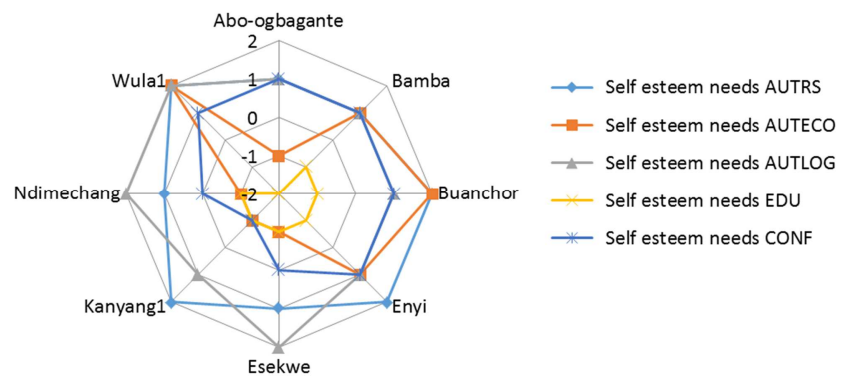

Figure 5. Spider diagram showing result of self-esteem needs in the communities.

The self-esteem need of the communities looks at autonomy with regards to resource regulation, economic choices, local governance in the communities as well as education and confidence in negotiating with external agencies. The trend of the component for this indicators for the communities sampled is presented in Figure. 5 above.

An overwhelming 100\% of communities sampled had respect for traditional institution and leadership.

In terms of autonomy to regulate resources, $50 \%$ of communities sampled had much improvement (score 2) while another $50 \%$ of communities sampled had slight improvement (score 1) for this indicator.

$50 \%$ of communities sampled had slight decline (score -1 ) with regards to autonomy to regulate their economic activities. $25 \%$ of communities sampled had slight improvement (score1) for this indicator and another $25 \%$ of communities sampled had much improvement (score 2) in terms of autonomy in economic activities indicator.62.5\% of communities sampled had slight increase (score 1) with regards to autonomy over local governance indicator. $37.5 \%$ of communities sampled had much improvement (score 2).

With regards to education indicator, $75 \%$ of communities sampled had slight decline (score -1) while 25\% of communities sampled had much decline (score -2) for education indicator.

$62.5 \%$ of communities sampled had slight improvement (score 1) in terms of their confidence level to negotiate with external agencies. 2. 5\% of communities sampled had slight decline (score -1) for this indicator. Another community representing another $25 \%$ of communities sampled had no change (score 0 ) for this indicator.

\subsection{Cultural Needs}

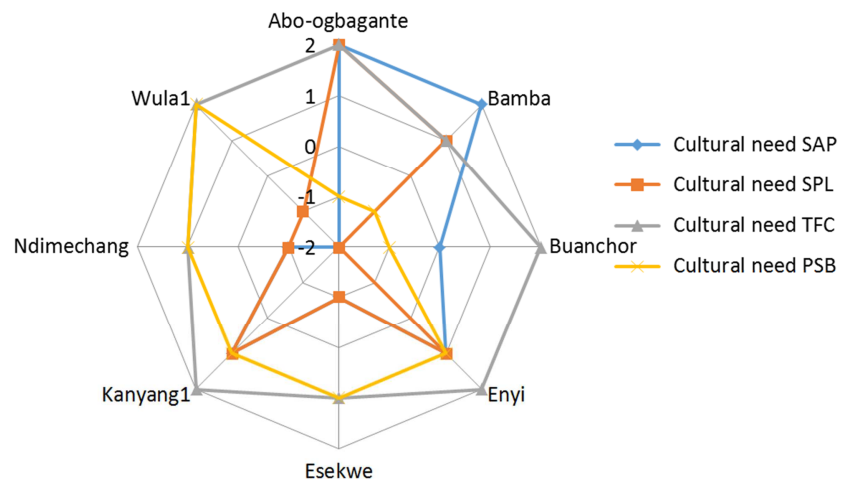

Figure 6. Spider diagram showing result of spiritual and cultural needs in communities.

The indicators of cultural or spiritual needs in the communities include sacred places, spiritual leadership, traditional festivals and practice of spiritual beliefs. The trend of these indicators for various communities sampled is represented in Figure. 6 above.

$12.5 \%$ of communities sampled had much decline (score 2 ) in terms of sacred places indicator prior to the beginning of REDD + activities. $25 \%$ of communities sampled had slight decline (score -1), while $12.5 \%$ of communities sampled had no appreciable change (score 0) for this indicator.

$12.5 \%$ of communities sampled had much decline (score 2) for spiritual leadership indicator while $37.5 \%$ of communities sampled had slight decline (score -1 ). $37.5 \%$ of communities sampled had much improvement (score 2) for the spiritual leadership indicator.

$62.5 \%$ of communities sampled had much improvement (score 2) in terms of traditional festival indicator, 37.5\% of communities sampled had slight improvement (score 1) for this indicator.

$50 \%$ of communities sampled had slight improvement (Score 1) with regards to practice of spiritual belief indicator while $12.5 \%$ of communities sampled had much improvement (score 2) for this indicator. However, 37.5\% of communities sampled had slight decline (score -1) with regards to this indicator.

\section{Recommendation}

This study uses a Community Wellbeing Assessment (CWA) tool to assess some socio-economic indicators in communities in Afi and Mbe pilot REDD+ sites in Cross River State, Nigeria. The results of the indicators assessed which include Basic needs, Safety needs, Belonging needs, Self-esteem needs and Cultural needs in the communities 
sampled were discussed above.

Through asking people their experiences and judgment, with a set of question in a survey, a measure of wellbeing could be obtained to generate evidence which could influence decisions of policy makers [22].

Some of the gaps identified in the study formed the basis for recommendations proffered. These recommendations include:

(1) The need for the government to scale up their food subsidy program to REDD+ communities. This could be in the form of direct food distribution, subsidized food sale, financial assistance for food purposes. This is due to glaring food security challenge posed to communities implementing REDD + as evidenced in the study. The food subsidy would be a short term measure pending the materialization of alternative livelihood options to be developed by government for these communities.

(2) In creating alternative livelihoods for the forest dependent communities, government should consider offering training in skill acquisition programs for members of the communities. It is worth mentioning that the proposed training in bee rearing (Apiculture) being developed by government is not enough, training must be provided in diversified skill set like Carpentry, tailoring in line with the opinion of the communities. Skill in Poultry and fish farming (Aquaculture) are also needed especially to deliver the protein needs to the communities since, according to them, they cannot hunt games indiscriminately in order to protect biodiversity. Such diversified livelihood that will bring socio-economic improvement through job creation as seen in Ekuri community in Cross River state should be scaled-up in the context of REDD+ [23]). Experience in Asia has shown that providing broader livelihood options and alternative income generating activities outside forestry sector could help in poverty reduction activities for forest dependent activities [24]. This is in line with opinion that ecological conditions is an important pre-requisite used by resource users to develop their livelihood activities and also leverage on sustainable development [25].

(3) Another means of supporting the communities is to provide some fund for micro-finance on a revolving basis. An example from Nepal of such scheme has been found to improve the livelihoods of local farmers [26]. Through farmers' cooperative (Cocoa and Banana farmers) and women in small cooperative groups, the micro-finance scheme could help develop commercial activities on a sustainable basis like cultivation of fresh vegetables among women in the communities. Further, the microcredit scheme option is important especially to address drivers of deforestation. This type of approach was also adopted in Ecuador in their Social Bosque program to conserve forest [27]. This type of scheme was recently started in Cross River state of Nigeria where the senate leader, through a financial institution, financed a micro-credit scheme to support youth and women in the state ${ }^{3}$. Hence a dedicated REDD + fund should be created that will serve the purpose of microcredit for these communities.

(4) With regards to land tenure, government should commence a phased approach to formalize the land titles of the communities implementing REDD + in line with recognition of customary land right. This is because REDD+ is a long tern initiative and there is need for the security of land tenure of the community in case of regime change in government and also to give the community carbon right. The implementation of REDD+ without giving due consideration to land especially as it affects the vulnerable in the community can trigger social unrest. This has been documented in Kenya [28]).

(5) Also, given the dearth of natural disaster in these communities like wind storm that reduced agricultural yield in some communities, there is need for a microinsurance scheme for farmers in these communities. An international organization, Oxfam, has supported small scale farmers in Ethiopia with micro-insurance which protects against extreme weather like drought. This type of risk insurance is needed to protect poor farmers in REDD+ communities against extreme weather events like landslide that damaged their crops and livelihood and as a means of improving their resilience to extreme weather conditions [29].

(6) Advocacy should be targeted at communities that do not include women in the leadership positions in local governance at community level, apparently, due to cultural factors. At least $25 \%$ of leadership positions should be reserved for women in the communities in line with gender mainstreaming in conservation activities.

(7) Access should be granted to members who want to perform cultural festivals in sacred sites in the forest and those willing to access herbs for alternative healing with strong monitoring in place to avoid illegal activities since some members were barred from accessing the forest for traditional activities and herbs extraction. This is important in the context of cultural sustainability.

\section{Conclusion}

The free dictionary defines safeguard as one that serves as protection or a guard, a safe conduct, protective stipulation or a precautionary measure ${ }^{4}$.

The word "safeguard" is also used to refer to measures to prevent and mitigate undue harm from investment or developmental activities. In the context of REDD + , however, social safeguard implies measures to protect non-carbon

\footnotetext{
3 Compass Newspaper, Monday 31, 2012.Weblink: http://www.compassnewspaper.org/index.php/component/content/article/90-frontpage-/11232-senate-leader-floats-micro-credit-scheme 4 Free Dictionary.http://www.freedictionary.com/safeguard
} 
forest values. This include risk posed to indigenous people. This include their language, culture, spiritual beliefs and more importantly, their land and livelihood.

In view of the risk involved in REDD + implementation, and especially as evidenced from this study, there is need to put in place safeguard measures in REDD+ to serve the interest of the forest dependent communities. The United Nations Framework Convention on Climate Change (UNFCCC) requires countries to provide information regarding safeguards put in place especially those that relates to social issues in forest governance. This will respect for the rights of local communities as it relates to their benefit and also prevent the elite from shortchanging the forest dependent community. This study opined that by giving consideration to socio-economic objectives in REDD+, there is the possibility of generating data that will contribute to effective safeguard information system which will help in achieving carbon and biodiversity goals and the sustainability of REDD+ activities itself.

Lessons from past experience in Clean Development Mechanism (CDM) in forestry sector (Afforestation /Reforestation) had shown that involvement of local community is important for project sustainability as well as deal with risk of non-permanence and leakage by developing community capabilities early in the readiness phase. This study, therefore, concludes that there is need for strong safeguard to be put in place early to protect communities against negative impact of REDD+.

Annexe 1: Table 1 showing scoring for Community Wellbeing Assessment (CWA) of sampled Communities in Afi/Mbe Mountains, Boki LGA, and Cross River State.

Table 1. Showing scoring for Community Wellbeing Assessment (CWA) of sampled Communities in Afi/Mbe Mountains, Boki LGA, Cross River State.

\begin{tabular}{|c|c|c|c|c|c|c|c|c|c|c|c|c|}
\hline \multirow[b]{2}{*}{ Community name } & \multicolumn{3}{|c|}{ Basic needs } & \multicolumn{6}{|c|}{ Safety/ security needs } & \multicolumn{3}{|c|}{ Belonging/social needs } \\
\hline & Food & HLTH & SLTR & sett & SVNG & ALT & ins & COMFUN & CON & SOC & WOMECON & WOMLDR \\
\hline Abo-Ogbagante & -1 & -2 & -2 & 2 & -2 & -1 & 0 & -1 & 1 & 2 & 1 & 1 \\
\hline Bamba & -2 & -2 & -1 & 2 & 0 & 1 & 0 & -1 & 1 & 2 & 2 & 2 \\
\hline Buanchor & -1 & -1 & 1 & 2 & 1 & 0 & 0 & -1 & 2 & 2 & 2 & 2 \\
\hline Enyi & -1 & -2 & -1 & 1 & 0 & 0 & 0 & 1 & 1 & 2 & 2 & 2 \\
\hline Esekwe & -2 & 0 & 0 & 2 & 0 & 0 & 0 & -2 & -1 & 1 & 1 & -2 \\
\hline Kanyang1 & -2 & -2 & -1 & 2 & 0 & -1 & 0 & -2 & 2 & 1 & 1 & 1 \\
\hline Wula 1 & -2 & 0 & 0 & 2 & -1 & 1 & 0 & -1 & 2 & 2 & 1 & 2 \\
\hline
\end{tabular}

Table 1. Continued

\begin{tabular}{|c|c|c|c|c|c|c|c|c|c|c|c|c|c|}
\hline \multirow[b]{2}{*}{$\begin{array}{l}\text { Community } \\
\text { name }\end{array}$} & \multicolumn{4}{|c|}{ Belonging/social needs } & \multicolumn{5}{|c|}{ Self-esteem needs } & \multicolumn{4}{|c|}{ Spiritual/Cultural needs } \\
\hline & ASCRSC & ASCLDR & EQBS & TIL & AUTRS & AUTECO & AUTLOG & EDU & CONF & SAP & SPL & TFC & PSB \\
\hline $\begin{array}{l}\text { Abo - } \\
\text { Ogbagante }\end{array}$ & 2 & 1 & -1 & 2 & 1 & -1 & 1 & -2 & 1 & 2 & 2 & 2 & -1 \\
\hline Bamba & 2 & 2 & 2 & 2 & 1 & 1 & 1 & -1 & 1 & 2 & 1 & 1 & -1 \\
\hline Buanchor & 2 & 2 & 2 & 2 & 2 & 2 & 1 & -1 & 1 & 0 & -2 & 2 & -1 \\
\hline Enyi & 2 & 2 & 2 & 2 & 2 & 1 & 1 & -1 & 1 & 1 & 1 & 2 & 1 \\
\hline Kanyang1 & 2 & 1 & 1 & 2 & 2 & -1 & 1 & -1 & -1 & 1 & 1 & 2 & 1 \\
\hline Ndimechang & 0 & 1 & 1 & 2 & 1 & -1 & 2 & -1 & 0 & -1 & -1 & 1 & 1 \\
\hline Wula 1 & 2 & 0 & 1 & 2 & 2 & 2 & 2 & -2 & 1 & -2 & -1 & 2 & 2 \\
\hline
\end{tabular}

HLTH: Health; SLTR: Shelter; Sett: Settled; SVNG: Savings; ALT: Alternative economic activities; Ins: Insurance; COMFUN: Community

Funds; CON: Conservation activities; SOC: Social groups; WOMECON: Involvement of women in economic activities; WOMLDR: Involvement of women in leadership; ASCRSC: Equality in access to resources ;ASCLDR: Equality in access to leadership; EQBS: benefit sharing commensurate with contribution; TIL: Traditional institution leadership; AUTRS: Autonomy to regulate resources; AUTECO: Autonomy on economic choices; AUTLOG: Autonomy over local governance; EDU: Education; CONF: Confidence: SAP: Sacred places; SPL: Spiritual leadership; TFC: Traditional festival; PSB: Practice of spiritual beliefs.

\section{References}

[1] UNFCCC (2010). Cancun Agreement: http://unfccc.int/meetings/cancun_nov_2010/items/6005.php.

[2] Kaczan David, Swallow Brent, Adamowicz Vick, \& Vihemäki Heini (2011). Designing an Incentive Program to Reduce Onfarm Deforestation in the East Usambara Mountains, Tanzania. University of Alberta.

[3] Kanowski, Peter, McDermott Constance, Cashore Benjamin (2011). Implementing REDD+: lessons from analysis of forest governance. Environmental Science \&Policy14, 111-117.
[4] Food and Agricultural Organization0 (FAO) (2010) Global Forest Resources Assessment http://www.fao.org/docrep/013/i1757e/i1757e.pdf.

[5] McCarthy Oyebo, Francis Bisong and Tunde Morakinyo (2011): A UNDP and Federal Ministry of Environment preliminary Assessment of the context for REDD+ in Nigeria.

[6] Angelsen, Arild. (2008). How do we set the reference levels for REDD payments. Moving ahead with REDD: issues, options and implications, 53-64.

[7] Phelps Jacob, Webb Edward \& Agrawal Arun (2010). Does REDD+ threaten to recentralize forest governance? Science, 328(5976), 312-313. 
[8] Lopez-Casero Federico (2012). Towards REDD+ implementation. Strengtenening governance and law enforcement in Indonesia and Brazil through policy coordination and international cooperation. Reseacher's viewpoint.Institute for Global Environmental Strategy (IGES). http://www.iges.or.jp/en/commentary/commentary_201212_lo pez.html.

[9] Convention on Biological Diversity (CBD) (2010). Global Expert Workshop on Biodiversity benefits of REDD in Developing Countries.

http://www.cbd.int/doc/?meeting=EWREDD-01 (Web link accessed in November, 2012).

[10] Leonardo Crippa and Gretchan Gordon (2012). International Law Principles for REDD: The rights of Indigenous people and the legal obligations of REDD + actors. Published by Indian law resource center.

[11] Loft, L., Ravikumar, A., Gebara, M. F., Pham, T. T., Resosudarmo, I. A. P., Assembe-Mvondo, S., Tovar, J. G., Mwangi, E. \& Andersson, K. (2015) Taking stock of carbon rights in REDD+ candidate countries: concept meets reality. Forests 6: 1031-1060.

[12] UN-DRIP (2007). Resolutions adopted by the General Assembly; www.un.org/esa/socdev/unpfili/documents/DRIPS-en.

[13] Suneetha Subramanian and Pisupati Balakrishna (2009). Benefit sharing perspectives from enterprising communities: http://www.ias.unu.edu/sub_page.aspx? catID $=732 \& d d I I D=10$ 811.

[14] UN-REDD (2011b). UN-REDD program social \& environmental principles and criteria, Version 1. Six policy board meeting, Da Lat, Viet Nam. http://www.unredd.org/PolicyBoard/6thPolicyBoard/tabid/6893/default.aspx.

[15] Wildlife Conservation Society (WCS) 2012: Cybertracker field map for Afi/Mbe monitoring from remote sensing toolkit used by field officers.

[16] Ottong Joseph, Ering Simon, Akpan Felix (2010). The population situation in Cross River state of Nigeria and it's implication for socio-economic development: Observations from 1991 and 2006 censuses. Journal of emerging trends in educational research and policy studies 1 (1):36-42.

[17] Morgan Bethan, Adeleke Alade, Bassey Tony, Bergl Richard, Dunn Andrew, Fotso Roger, Gadsby Elizabeth, Gonder Katy, Greengrass Elizabeth, Koulagna Denis, Mbah Grace, Nicholas Aaron, Oates John, Omeni Fidelis, Saidu Yohanna, Sommer Volker, Sunderland-Groves Jacqueline, Tiebou Joseph, and Williamson Elizabeth.(2011). Regional action plan for the conservation of the Nigeria-Cameroon Chimpanzee. IUCN/SSC primate specialist group and Zoological society of San Diego. CA. USA.

[18] Governors Climate Forum (GCF) (2010). Database. http://www.gcftaskforce.org.
[19] Narayanasamy, Nammalvar. (2009). Participatory rural appraisal: Principles, methods and applications. New Delhi: Sage publications.

[20] Huitt, Williams. (2007). Maslow's hierarchy of needs. Educational Psychology Interactive, 1-5. http://www.edpsycinteractive.org/topics/conation/maslow.html.

[21] Clarke, Matthew (2006). Assessing well-being using hierarchical needs, In Mc Gillivray, Mark and Matthew Clarke, 2006, Understanding human well-being, United Nations University World Institute for Development Research, United Nations University press.

[22] New Economic Foundation (NEF) (2010). http://www.neweconomics.org/sites/neweconomics.org/files/ measuring-our.programs.pdf.

[23] UNDP (2012). Ekuri Initiative, Nigeria. Equator Initiative case study series. New York, N. Y.

http://www.equatorinitiative.org/images/stories/winners/66/cas estudy/case_1348153030.pdf.

[24] Regional Community Forestry Training Center for Asia and the Pacific (RECOFTC) (2008). People, Forest, and Human well-being. Managing forest for people in a period of change. A synthesis report. Published by RECOFTC. http://www.recoftc.org/site/uploads/content/pdf/SynthesisRep ort_Final_56.pdf9.

[25] Coomes, Oliver T., Takasaki, Yoshito, Rhemtulla, J. M., 2016. Forests as landscapes ofsocial inequality: tropical forest cover and land distribution aong shifting cultivators. Ecol. Soc. 21, 20 .

[26] Lopez-Casero Federico and Ukesh Bhuju (2009). From shifting cultivation to sustainable livelihood creation; strengthening marginalized communities through institutional development of micro finance for Agro forestry and energyefficient technologies-Forest conservation, Livelihoods and Rights project. Institute for Global Environmental Strategies (IGES).

[27] de Koning Free, Aguiñaga, Marcel, Bravo Manuel, Chiu Marco, Lascano Max, Lozada Tannya, \& Suarez Luis. (2011). Bridging the gap between forest conservation and poverty alleviation: the Ecuadorian Socio Bosque program. Environmental Science \& Policy, 14(5), 531-542.

[28] Chomba, Susan, Kariuki, Juliet, Friis Lund, Jens, Sinclair, Fergus, 2016. Roots of inequity:how the implementation of REDD+ reinforces past injustices. Land Use Policy 50,202213.

[29] Oxfam (2012). R4 rural resilience initiative quarterly report. January-March 2012. Published by Oxfam, America. http://www.oxfamamerica.org/publications/r4-rural-resilienceinitiative-19k. 